\title{
Effects of climate change on agriculture water demand in lower Pak Phanang river basin, southern part of Thailand
}

\author{
Natapon Kaewthong ${ }^{1}$, and Pakorn Ditthakit ${ }^{2, *}$ \\ ${ }^{1}$ Graduate Student, School of Engineering and Resources, Walailak University, Nakhon Si Thammarat, Thailand \\ ${ }^{2}$ Assistant Professor, School of Engineering and Resources, Walailak University, Nakhon Si Thammarat, Thailand
}

\begin{abstract}
The aim of the research is to analyse the effects on agricultural water demand in the Lower Pak Phanang River Basin area due to climate change. The climate data used in the analysis were rainfall, maximum, minimum, and average temperatures. The climate datasets were obtained from statistical downscaling of global circulation model under the CMIP5 project by means of bias correction with Optimizing Quantile Mapping implemented by the Hydro and Agro Informatics Institute. To determine agriculture water demand, reference evapotranspiration (ETo) based on Hargreaves method was calculated for both baseline climate data (1987-2015) and forecasted climate data in 2038. For agriculture water demand in the Pak Phanang river basin, we considered paddy field, palm oil, rubber, grapefruit, orchard, vegetable, ruzy and biennial crop, based on land use data of the Land Development Department of Thailand in 2012. The results showed that forecasted agriculture water demand in 2038 with existing land use data in 2012 will be increased with the average of $18.9 \%$ or $61.78 \mathrm{MCM}$ as compared to baseline climate condition. Both water demand and supply management measures would be suitably prepared before facing unexpected situation.
\end{abstract}

\section{Introduction}

Climate change affects several aspects of global community, especially food and livelihood security. It is therefore inevitable to comprehend such phenomena and to prepare for facing negative effect occurrences. In recent years, many studies have shown that Thailand has the potential to be affected by climate change. According to Thailand's Department of Meteorology, from 1981 to 2007, Thailand had an average temperature increase of about 1 degree Celsius. The Intergovernmental Panel on Climate Change (IPCC) predicted that in 2050 Thailand will have an average temperature rise of 1.2-1.9 degrees Celsius, and there is likely to increase sea surface temperatures. The moment 10 years ago, the water temperature in the sea area of South East Asian with a temperature increase of $0.1-0.3^{\circ} \mathrm{C}$ (1951 to 2000). The results from several researches show that Thailand will have a lower number of rainy days and lower rainfall, especially during the dry season, on the other hand, there is a high rainfall intensity during the rainy season [1-6]. It has been found that this change in agricultural production has a significant effect on agricultural output, especially rice, which is likely to decrease [7-9]. For this research, we analyzed and compared the amount of water demand of each plant species based on the Hargreaves method [10] using climate data including highest and lowest temperatures, average temperatures, and daily rainfall for baseline and future events.

\subsection{Study Area.}

The Pak Phanang River Basin (PPRB) is located on the east coast of southern Thailand. Pak Phanang River is the main waterway which has a length of about $180 \mathrm{~km}$ covers Pak Phanang District, Hua Sai District, Ron Phibun District, Chian Yai District, Chulabhorn District, Phra Phrom District, Chalerm Phrakiat District, Cha-am District and some parts of Lan Saka District and Nakhon Si Thammarat District. The terrain can be divided into three parts: the upper watershed is a high mountain and parallel to the coast. The middle part of watershed is alternating area between high and low, and the lower part of watershed is adjacent to the Gulf of Thailand, where the flood plain and some lowland areas are below normal sea level. In the past, PPRB had abundance of a swampy forest area in the middle part of watershed. Such area was a significant natural water source for agriculture. However, when the swamp area was destroyed, the Lower PPRB has been facing water shortage as well as sea water intrusion problems. Additionally, the Lower Lower PPRB, which is a coastal lowland, has been affected by sea level rise and fall and deposited by sediment at the river mouth estuary. Such situations affects to deficiency of cultivation, economic downturns, and people emigration. In the year 1992, His Majesty the late King Bhumibol Adulyadej gave an order problemsolving measure for the Pak Panang watershed,

*Corresponding author: 
including three main tasks: 1) constructing Pak Phanang floodgate to solve the water shortage problem for agriculture and household use, 2) dredging the canal for the purpose of drainage during rainy season and storing water during dry season, 3) dividing land use areas into freshwater and saltwater areas by construction of flood gates and water control structure along the tributaries. The command areas and water control structures of the Lower PPRB are shown in Figure 1. It shows components of the system including main river (Pak Phanang river), canals, command area, locations of pumping station, agricultural water demand in each command area, water flow direction, return flow, and water storage or community pond in each command area. Main Canal (MC) command area is the area which irrigation water is obtained from pumping water from river or canals into gravitational irrigation canal system, whilst Main Drainage (MD) command area which irrigation water is obtained from pumping water from river or canals into drainage canal system (water flowing with adverse slope). River and canals storage system of approximately 70 million cubic meters are the main water sources of the study area, especially during dry season. It is insufficient for more growing water demand. The schematic diagram of the Lower PPRB in Figure 2 shows the linkage components of the system, including Pak Phanang River, canals, command areas, locations of pumping station, initial water flow direction, and return flow.

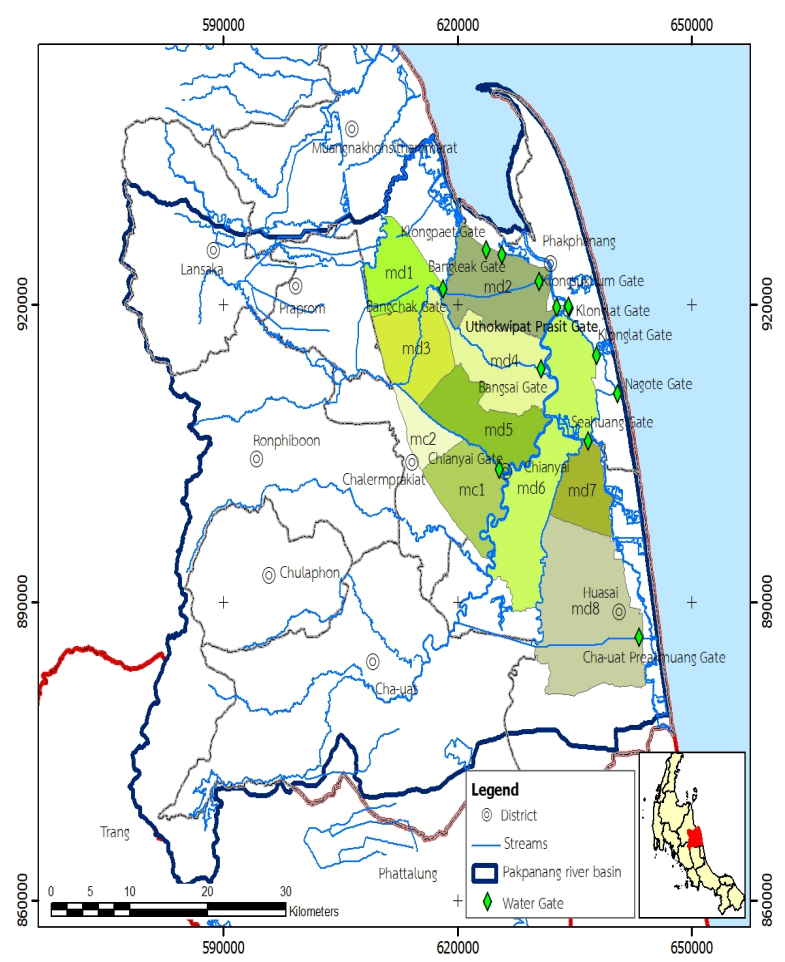

Fig. 1. The command areas and water control structures of the Lower PPRB

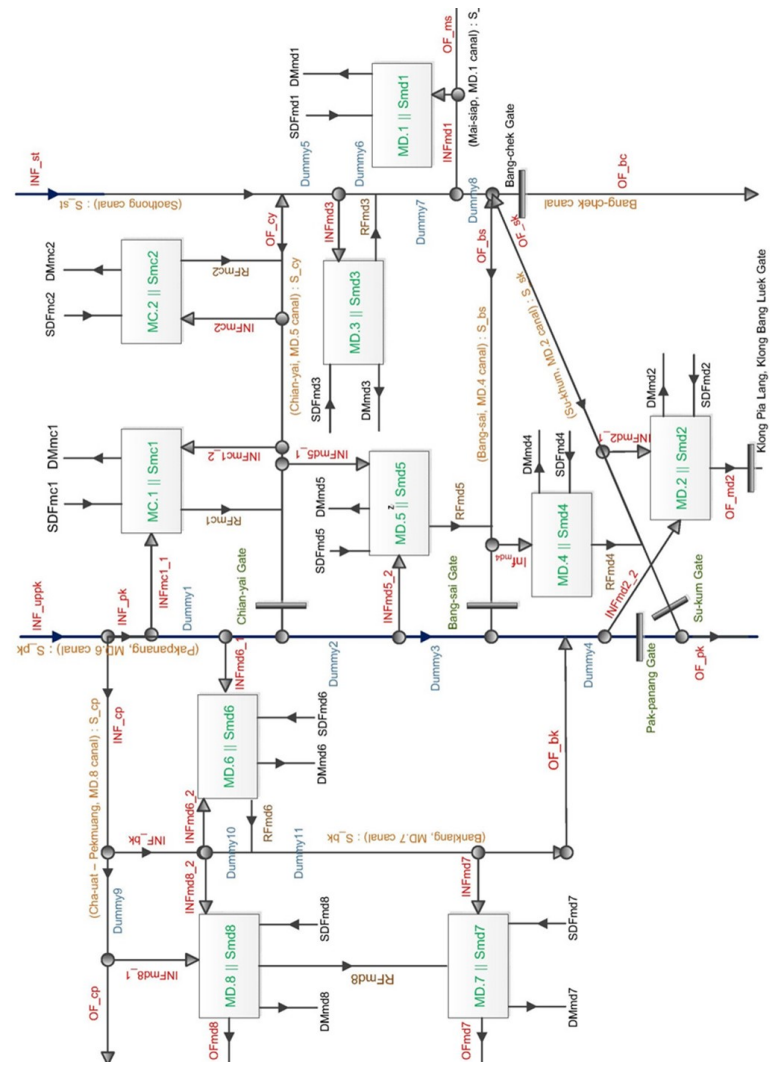

Fig. 2. The schematic diagram of the Lower PPRB

\subsection{Climate Change Data.}

This research used the rainfall data of the rainfall stations in the Pak Phanang watershed, consisting of 552004, 552007, 552010, 552011, 552023, 552025 and 552027 stations between 1987 and 2015. Agricultural water demand was estimated for both recorded climate data and forecasted climate data under climate change condition. The climate datasets were obtained from statistical downscaling of global circulation model under the CMIP5 (the world climate research program coupled model inter-comparison phase5) project. For downscaling of global circulation model, the Hydro and Agro Informatics Institute developed bias correction with Optimizing Quantile Mapping method. More accuracy was obtained when compared to using traditional bias correction method [11]. The climate conditions include 4-5 scenarios depending on the data portal contribution such as historical, RCP2.6, RCP4.5, RCP6.0 and RCP8.5. The concerning period can be separated into 4 periods such as historical scenario for 1 period (1979-2006) and RCP scenarios for 3 periods (2015-2039, 2045-2069 and 2075-2099). Furthermore, the bias corrected GCM data were conversed to the $0.25^{\circ}$ x $0.25^{\circ}$ gird format (885 grids) [12]. This study used the CNRM-CM5 model using the Scenario RCP4.5 and Scenario RCP8.5. 


\section{Methodology}

\subsection{Land Use Analysis}

Land use data in 2012 obtained from the Land Development Department of Thailand was used for determination of agricultural areas of the Lower Pak Phanang Basin. It was the third level of land use. Land use data consisted of paddy field, deserted paddy field, palm, tropical rain forest, swamp forest, mangrove forest, vegetable crop, biennial crop, rubber, deserted orchard, perennial, industry land, aquaculture land, river/canal/irrigation canal, soil puddle/sand/lateritic/old mine, farm pond, and others. It indicated that the Lower PPRB had an area of about 66,772.32 acres and the most used areas were paddy field with total area of 39,272 hectares, equivalent to 42.82 percent of total area. The second is the total area of 12,101 hectares of palm plantation, which is 13.20 percent of the total area.

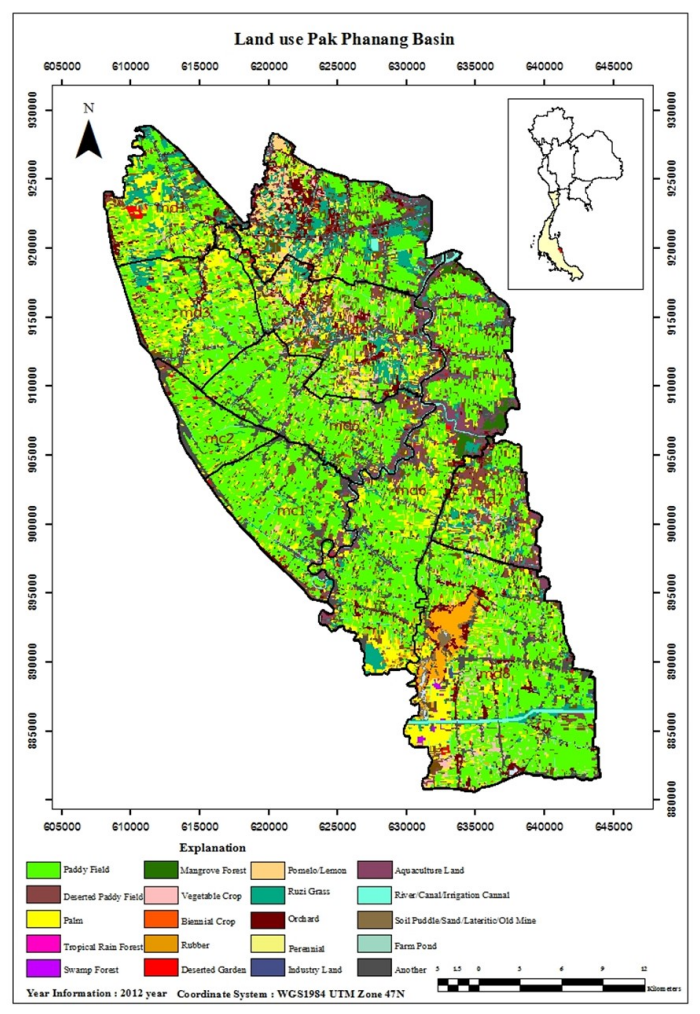

Fig. 3. Map showing land use classification in 2012.

\subsection{Water Demand Analysis}

The agricultural water demand analysis in the Lower PPRB was based on the calculation of the water demand for 8 plant species, including paddy field, palm oil, rubber, grapefruit, orchard, vegetable, ruzy and biennial crop. It was analysed for both baseline climate data (1987-2015) and forecasted climate data in 2038. Hargreaves equation [10] as shown in equation 1 was applied herein for determination of reference evapotranspiration (ETo) since it required only four climate data, including rainfall, maximum, minimum, and average temperatures. It is coincident with climate data obtained from the Hydro and Agro Informatics Institute. The water equivalent of the extraterrestrial radiation can be derived from locations of climate stations. And water requirements at farm level were analysed using equation 2. Due to number of pages limitation, the more detail information about Kc values for each plant can be found in Plant Coefficient (kc) of 40 plants [13] from Office of Water Management and Hydrology, Royal Irrigation Department, Thailand.

The Hargreaves equation [10] can be written as:

ETo $=0.0023 R a(T+17.8) \sqrt{T \max -T \min }$ where

ETo is reference evapotranspiration $\left(\mathrm{mm} \mathrm{d}^{-1}\right)$;

$\mathrm{Ra}$ is the water equivalent of the extraterrestrial radiation $\left(\mathrm{mm} \mathrm{d}^{-1}\right)$;

Tmax, Tmin and $\mathrm{T}$ are the daily maximum, minimum and mean air temperature $\left({ }^{\circ} \mathrm{C}\right)$.

Water demand of plants at farm level can be calculated as:

$$
\mathrm{W}_{\text {farm }}=\mathrm{ET}_{\mathrm{c}}+\mathrm{W}_{\mathrm{LP}}+\mathrm{W}_{\mathrm{PS}}+\mathrm{W}_{\mathrm{L}}-\mathrm{P}_{\mathrm{e}}
$$

Where

$\mathrm{W}_{\text {farm }}$ is water demand of plants at farm level;

$\mathrm{ET}_{\mathrm{c}}$ is crop evapotranspiration $\left(\mathrm{ET}_{\mathrm{c}}=\mathrm{K}_{\mathrm{c}} \mathrm{x} \mathrm{ET}_{\mathrm{o}}\right)$;

$\mathrm{K}_{\mathrm{c}} \quad$ is crop coeffiecient;

$\mathrm{W}_{\mathrm{LP}}$ is water required for land preparation;

$\mathrm{W}_{\mathrm{PS}}$ is percolation and seepage losses of water from paddy field;

$\mathrm{W}_{\mathrm{L}}$ is water to establish standing water layer;

$\mathrm{P}_{\mathrm{e}}$ is effective rainfall.

\section{The results}

Table 1 shows water demand of plants per area. It indicated that from forecasting climate change in the year 2038 resulted in increasing average water demand of plants per area in the Lower PPRB during dry season of approximately 22 percent. The highest percentage change of increasing water demand of plants per area were ruzi grass and biennial crop of about 27, and 26 percent. The percentage change of increasing water demand of rubber, orchard, vegetable, and grapefruit was $22,22,22$, and 23 , respectively. And the lowest percentage change of increasing water demand of plants per area were palm oil and paddy field of about 17 percent. Additionally, more agricultural water demand for all command areas in the Lower PPRB Basin was approximately 61.78 million cubic meters. It required 326.57 million cubic meters for current climate condition and 388.35 million cubic meters in the year 2038. 
Table 1. Water demand of plants per area.

\begin{tabular}{|c|c|c|c|}
\hline \multirow{2}{*}{ Plant Types } & \multicolumn{3}{|c|}{$\begin{array}{c}\text { Water demand of plants per area } \\
\text { in cubic meter per hectares (Jan-Apr) }\end{array}$} \\
\cline { 2 - 4 } & $\begin{array}{c}\text { Current } \\
\text { climate }\end{array}$ & $\begin{array}{c}\text { Climate } \\
\text { change }\end{array}$ & $\begin{array}{c}\text { Percentage } \\
\text { change }\end{array}$ \\
\hline Paddy field & $4,881.25$ & $5,749.60$ & +17.79 \\
\hline Palm oil & $6,488.75$ & $7,625.62$ & +17.94 \\
\hline Rubber & $1,016.88$ & $1,241.80$ & +22.12 \\
\hline Grapefruit & $4,331.25$ & $5,361.49$ & +23.78 \\
\hline Orchard & $5,084.38$ & $6,208.99$ & +22.12 \\
\hline Vegetable & $2,890.00$ & $3,531.09$ & +22.17 \\
\hline Ruzy & $3,290.63$ & $4,189.52$ & +27.32 \\
\hline Biennial crop & $4,887.50$ & $6,166.13$ & +26.16 \\
\hline
\end{tabular}

\section{Discussion and conclusions}

This research aimed to study the impacts on the amount of water demand of plants in response to climate change in the year 2038 to be ready to deal with the situation in the future. The results showed that in the future, especially during the dry season, the agricultural water demand in the Lower PPRB Basin, a complicated irrigation area, will be higher with the average water demand of plants per area of approximately 22 percent due to higher temperature and lower rainfall. These coincided with the previous research [14, 15]. The preparedness measures for facing an unexpected event could be significantly considered for all concerning agencies as well as local farmers, for example, optimal cropping pattern, water infrastructure development projects, community or farm pond promoting rainwater harvesting.

\section{Acknowledgment}

This research is based on the cooperation of all sectors in the area. The research results will lead to the utilization for water management in the area in the future. The authors thank to irrigation officers and local stakeholders for their valuable and beneficial recommendation to complete the research study.

\section{References}

1. W. Chaowiwat, O. Kamnoet and S. Weesakul (2016) Future Drought Characteristics over Thailand by Using Bias Corrected Multi CMIP5 General Circulation Model, International Conference of Multidisciplinary Approaches on UN Sustainable Development Goals (UNSDGs), December 28th - 29th, 2016.

2. Denny Marks (2011). Climate Change and Thailand: Impact and Response, Contemporary Southeast Asia Vol.33, No.2 (2011), pp.229-58

3. W.Chaowiwat, P.Danusatianpong, K.Sarinnapakorn and S.Boonya-aroonnet (2017). Extreme Climate Prediction for Water Management Community Network under Changing Climate, The $22^{\text {nd }}$ Nation Convention on Civil Engineering July 18-22, 2017, Nakhon Ratchasima, THAILAND
4. IPCC, 2007 : Summary for Policymakers. In : Climate Change 2007 : The Physical Science Basic. Contribution of Working Group I to the Forth Assessment Report of the Intergovernmental Panel on Climate Change [Solomon, S.,D. Qin, M. Manning, Z. Chen, M. Marquis, K.B. Averyt, M.Tignor and H.L. Miller (eds.)] Cambridge University Press, Cambridge, United Kingdom and New York, NY, USA.

5. Thanapakpawin, P.,Boonya-aroonnet, S., Chankarn, A., Chitradon, R., \& Snidvongs, A. (2011). Thailand Drought Risk Management: Macro and Micro Strategies. In R.Shaw, \& H.Nguyen, Droughts in Asian Monsoon Region (Vol.8, pp. 121-140). Emerald Books.

6. Royol Chitradon, Surajate Boonya-aroonnet and Porranee Thanapakpawin (2009). Risk Management of Water Resources in Thailand in the Face of Climate Change. Sasin Journal of Management 2009, pp.64-73

7. Jintana Kawasaki and Srikantha Hereth (2011). Impact Assessment of Climate Change on Rice Production in Khon Kaen Province, Thailand. J.ISSAAS Vol.17, No.2 :14-28 (2011)

8. John Felkner, Kamilya Tazhibayeva and Robert Townsend (2009). Impact of Climate Change on Rice Product in Thailand. Am Econ Rev.2009 May ; 99(2) :205-210.

9. Mukand S. Babel, Anshul Agarwal, Dillip Kumar Swain and Srikantha Herath (2011). Evaluation of climate change impacts and adaptation measures for rice cultivation in Northeast Thailand. Climate Research Vol.46 :137-146,2011.

10. Hargreaves, G.H., Samani, Z.A., 1985. Reference crop evapotranspiration from temperature. Appl. Eng. Agric. 1(2), 96-99.

11. W. Chaowiwat, T. Charoensuk, P. Srisompron and S.Boonya-aroonnet (2015). Development of Statistical Downscaling of Global Circulation Model Data by Optimizing Quantile Mapping Method. The 20th National Convention on Civil Engineering 8-10 July 2015, Chonburi, Thailand

12. Taylor KE, Stouffer RJ, Meehl GA (2012). An Over of CMIP5 and the Experiment Design. Bull Am Meteorol Soc 93(4) :485-498.

13. Office of Water Management and Hydrology, Royal Irrigation Department, Thailand (2003). Plant Coefficient ( $k c)$ of 40 plants. Retrieved from http://water.rid.go.th/hwm/cropwater/CWRdata/Kc/ kc_th.pdf

14. Y. Wada, D.Wisser, S.Eisner, M.Florke, D.Gerten, I.Haddeland, N.Hanasaki, Y.Masaki, F.Portmann, T.Stacke, Z.Tessler and J.Schewe (2013). Multimodel projection and uncertainties of irrigation water demand under climate change. Geophysical Research Letters, Vol. 40, 4626-4632.

15. Shamsuddin Shahid (2011). Impact of climate change on irrigation water demand of dry season Boro rice in northwest Bangladesh. Climate Change (2011) $105: 433-453$ 